\title{
Update on Monoterpenes as Antimicrobial Agents: A Particular Focus on p-Cymene
}

\author{
Anna Marchese ${ }^{1}$, Carla Renata Arciola ${ }^{2,3}$, Ramona Barbieri ${ }^{1}$, Ana Sanches Silva 4,5, \\ Seyed Fazel Nabavi ${ }^{6}$, Arold Jorel Tsetegho Sokeng ${ }^{7}$, Morteza Izadi ${ }^{8}$, Nematollah Jonaidi Jafari ${ }^{8}$, \\ Ipek Suntar ${ }^{9}$, Maria Daglia ${ }^{7, *}$ (iD) and Seyed Mohammad Nabavi ${ }^{6, *}$ \\ 1 Sezione di Microbiologia DISC-IRCCS San Martino-IST University of Genoa, 16132 Genoa, Italy; \\ anna.marchese@unige.it (A.M.); ramona.barbieri@unige.it (R.B.) \\ 2 Research Unit on Implant Infections, Rizzoli Orthopaedic Institute, via di Barbiano 1/10, \\ 40136 Bologna, Italy; carlarenata.arciola@ior.it \\ 3 Department of Experimental, Diagnostic and Specialty Medicine (DIMES), University of Bologna, \\ Via San Giacomo 14, 40126 Bologna, Italy \\ 4 National Institute for Agricultural and Veterinary Research (INIAV), I.P., Vairão, 4480 Vila do Conde, \\ Portugal; anateress@gmail.com \\ 5 Center for Study in Animal Science (CECA), ICETA, University of Oporto, 4051-401 Oporto, Portugal \\ 6 Applied Biotechnology Research Center, Baqiyatallah University of Medical Sciences, \\ Tehran 19395-5487, Iran; nabavisf@gmail.com \\ 7 Department of Drug Sciences, Medicinal Chemistry and Pharmaceutical Technology Section, \\ University of Pavia, 27100 Pavia, Italy; aroldjorel.tseteghosokeng@universitadipavia.it \\ 8 Health Research Center, Baqiyatallah University of Medical Sciences, Tehran 19395-5487, Iran; \\ morteza_izadi@yahoo.com (M.I.); mjafari@hs.uci.edu (N.J.J.) \\ 9 Department of Pharmacognosy, Faculty of Pharmacy, Gazi University, Etiler, Ankara 06330, Turkey; \\ kriptogam@gmail.com \\ * Correspondence: maria.daglia@unipv.it (M.D.); nabavi208@gmail.com (S.M.N.); \\ Tel./Fax: +98-21-88617712 (M.D.); +39-0382-987388 (S.M.N.)
}

Received: 25 July 2017; Accepted: 11 August 2017; Published: 15 August 2017

\begin{abstract}
Cymene [1-methyl-4-(1-methylethyl)-benzene] is a monoterpene found in over 100 plant species used for medicine and food purposes. It shows a range of biological activity including antioxidant, anti-inflammatory, antinociceptive, anxiolytic, anticancer and antimicrobial effects. This last property has been widely investigated due to the urgent need for new substances with antimicrobial properties, to be used to treat communicable diseases whose diffusion in developed countries has been facilitated by globalization and the evolution of antimicrobial resistance. This review summarizes available scientific data, as reported by the most recent studies describing the antimicrobial activity of p-cymene either alone, or as the main component of plant extracts, as well as addressing the mechanisms of action of cymenes as antimicrobial agents. While p-cymene is one of the major constituents of extracts and essential oils used in traditional medicines as antimicrobial agents, but considering the limited data on its in vivo efficacy and safety, further studies are required to reach a definitive recommendation on the use and beneficial effects of p-cymene in human healthcare and in biomedical applications as a promising candidate to functionalize biomaterials and nanomaterials.
\end{abstract}

Keywords: antibacterial; antimicrobial; cymenes; monoterpenes

\section{Introduction}

Plant extracts and their secondary metabolites are rich sources of antimicrobial substances, including coumarins and psoralens, acetylenes, flavonoid and non-flavonoid polyphenols, and terpenes [1-5]. Monoterpenes (i.e., eucalyptol, borneol, camphor, bornylacetate, carvacrol, 
$(-)$-menthol, $\gamma$-terpinene, $(+)-\alpha$-pinene, $(-)-\beta$-pinene, and p-cymene) are the most important constituents of essential oils produced through liquid extraction and steam distillation of edible and medicinal plants [1]. p-Cymene [1-methyl-4-(1-methylethyl)-benzene] is an alkyl-substituted aromatic hydrocarbon found in nature, whose benzene ring features the substitution of a methyl and an isopropyl group, and which is considered to be the most important monoterpene compound occurring in aromatic plants, such as thyme and oregano. p-Cymene is found in more than 100 plant species, including many belonging to Thymus, Origanum, Ocimun (Lamiaceae), Eucalyptus (Mirtaceae), Protium (Burseraceae), and Artemisia (Asteraceae) genus [6]. This compound shows a variety of biological activities which include antioxidant, antinociceptive, anti-inflammatory, anxiolytic, anticancer and antimicrobial activities. In fact, recent in vivo investigations performed on experimental animal model systems (adult male Swiss mice), showed that p-cymene increases the activity of antioxidant enzymes, reducing oxidative stress $[7,8]$. In addition, it shows anti-inflammatory activity, being able to modulate cytokine production (tumor necrosis factor- $\alpha$-TNF- $\alpha$, interleukin-1 $\beta$-IL-1 $\beta$, interleukin-6-IL-6) in vitro (murine macrophage-like cell line RW 264.7) and in vivo (Female C57BL/6) by inhibiting nuclear factor- $\mathrm{KB}(\mathrm{NF}-\mathrm{kB})$ and mitogen-activated protein kinase (MAPK) signaling pathways involved in synthesis of pro-inflammatory cytokines [9]. The anti-inflammatory activity of p-cymene at least partly justifies its antinociceptive activity, as recorded in several in vivo studies performed on murine model systems $[8,10,11]$. Moreover, recent investigations report the antitumor activity of p-cymene and metal p-cymene complexes such as rutenium (II)- and osmium (II)-p-cymene complexes, which inhibit tumor proliferation through an antiangiogenic mechanism, cancer cell cytotoxicity, and anti-adhesion activity [12-14]. p-Cymene is the main antimicrobial compound in thyme, and a large body of evidence suggests that this monoterpene possesses antibacterial, antiviral and antifungal activities. This review reports the available data on the mechanisms of action of cymenes and summarizes major studies describing their antimicrobial activity, both alone or as main components of plant extracts, from the past five years.

\section{Chemistry}

p-Cymene (also known as 4-isopropyltoluene, 1-isopropyl-4methylbenzene or 1-methyl-4isopropylbenzene) is a naturally occurring compound, although it has two further geometric isomers, $\mathrm{m}$-cymene (with meta-substituted alkyl groups) and o-cymene (with ortho-substituted alkyl groups) which do not occur naturally $[5,15]$. p-Cymene is related to the monoterpenes. Monoterpenes themselves belong to the "terpenes", a larger class of organic compounds, which are the most representative components of essential oils [8,16]. Figure 1 shows the chemical structure of $p$-cymene, indicating the benzene ring with methyl and isopropyl substitutions. Some of the physical properties of this molecule are compiled in Table 1.

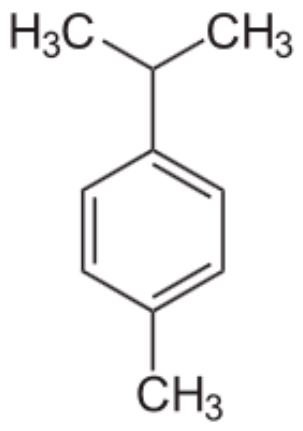

Figure 1. Chemical structure of p-cymene [17]. 
Table 1. Some physical properties of p-cymene [17].

\begin{tabular}{cc}
\hline Physical Property & Value \\
\hline Molecular Weight & 134.22 \\
Boiling Point & $177.1^{\circ} \mathrm{C}$ \\
log P (octanol-water) & 4.1 \\
Water Solubility & $23.4 \mathrm{mg} / \mathrm{L}$ \\
Vapor Pressure & $1.46 \mathrm{~mm} \mathrm{Hg}$ \\
Henry's Law Constant & $0.011 \mathrm{~atm}-\mathrm{m}^{3} / \mathrm{mole}$ at $25^{\circ} \mathrm{C}$ \\
Atmospheric OH Rate Constant & $1.51 \times 10^{-11} \mathrm{~cm}^{3} / \mathrm{molecule}-\mathrm{sec}$ at $2{ }^{\circ} \mathrm{C}$ \\
\hline
\end{tabular}

Medicinally, p-cymene is used to prevent coughs and eliminate phlegm [15] as well as being a flavouring agent, and being used in the production of fungicides and pesticides $[10,18]$. It is considered to be "generally recognised as safe" (GRAS) by the U.S. Food and Drug Administration [19]. Its potential in the prevention of protein glycation mediated diabetic complications has also been confirmed [15], and it has been suggested as an in vivo antioxidant compound due to its ability to reduce the formation of oxygen and nitrogen reactive species, acting as a potential neuroprotective agent in the brain. Therefore, it could be involved in the treatment of oxidative stress related diseases [7]. p-Cymene also acts as an analgesic/antinociceptive and anti-inflammatory [9-11] and has a vasorelaxant effect in rat mesenteric artery and aorta [20,21]. The odour of p-cymene has been described as woody and spicy [22]. Beaulieu \& Stein-Chisholm (2016) [23] have compiled the attributes of p-cymene from different sources as citrus, solvent, gasoline, kerosene, fresh, woody, spice, cumin, oregano, cilantro, green pepper and rancid.

\section{Sources}

p-Cymene has been identified in the essential oils of more than 100 plants and 200 foods. Tables 2 and 3 report the levels of p-cymene found in essential oils and plant-based foods, respectively. The composition and content of essential oils depend on several factors affecting the plant at harvest, including age, genetic factors, ripening stage, edaphoclimatic conditions and season of collection [24]. Therefore, the controlled culture of aromatic plants is recommended over the use of wild populations, in order to produce essential oils to be used in the food, pharmaceutical or cosmetic industries. Besides essential oils, p-cymene occurs in herbal drugs obtained from traditional medicinal plants. In fact, it is a component of folium eucalypti, which consists of the dried leaves of Eucalyptus globulus Labill (Myrtaceae) [25], fructus anethi, the dried ripe fruits of Anethum graveolens L. (Apiaceae) [26], and Cortex Magnoliae, the dried bark of Magnolia officinalis Rehder and Wilson, and M. obovata Thunb [27].

Table 2. p-Cymene levels in some essential oils.

\begin{tabular}{lccl}
\hline \multicolumn{1}{c}{ Matrix } & Content & Reference & \multicolumn{1}{c}{ Comments } \\
\hline \multicolumn{3}{c}{ Essential Oils } & \\
\hline Chenopodium ambrosioides L. & $16.20 \%$ & {$[28]$} & from Madagascar \\
Grapefruit peel essential oil & $0.12 \%$ & {$[29]$} & \\
Thymus kotschyanus & $9.80 \%$ & {$[30]$} & \\
Thymus vulgaris (thyme) & $15.2 \%$ & {$[30]$} & \\
Orange peel essential oil & $0.23-9.84 \%$ & {$[31]$} & \\
Tangerine & $4.70 \%$ & {$[32]$} & \\
Thymus vulgaris ct. Thymol & $5-10 \%$ & {$[33]$} & from Spain \\
(red thyme) & $5-10 \%$ & {$[33]$} & from Morocco \\
T. vulgaris & $11.5-35.7 \%$ & {$[34]$} & from Nefza (Tunisia) and 3 different \\
Oreganum vulgare L. Subsp. & & & harvest years (2007, 2008, 2009) \\
Glandulosum (Desf.) & & & \\
\hline
\end{tabular}


Table 2. Cont.

\begin{tabular}{lccl}
\hline \multicolumn{1}{c}{ Matrix } & Content & Reference & Comments \\
\hline \multicolumn{3}{c}{ Essential Oils } & \\
\hline Oreganum vulgare L. Subsp. & $27.3-46.3 \%$ & {$[34]$} & from Krib (Tunisia) and 3 different \\
Glandulosum (Desf.) & $45.90 \%$ & {$[35]$} & \\
Thymus vulgaris & $14.06 \%$ & {$[35]$} & \\
Ocimum gratissimum & $0.11 \%$ & {$[36]$} & \\
Mentha arvensis L. & $0.12 \%$ & {$[36]$} & \\
Mentha piperita L. & $1.03 \%$ & {$[24]$} & \\
Rosmarinus officinallis L. & $1.16 \%$ & {$[24]$} & \\
Cinnamomum zeylanicum Blume & & & \\
\hline
\end{tabular}

Table 3. p-Cymene levels in some food matrices.

\begin{tabular}{|c|c|c|c|}
\hline \multicolumn{4}{|c|}{ Fruits, Plants or Vegetables } \\
\hline $\begin{array}{l}\text { Star apple fruit } \\
\text { (Chrysophillum albidum) }\end{array}$ & $0.01 \mathrm{mg} / \mathrm{kg}$ & {$[22]$} & bitter and sour varieties \\
\hline $\begin{array}{l}\text { Star apple fruit } \\
\text { (Chrysophillum albidum) }\end{array}$ & $0.95 \mathrm{mg} / \mathrm{kg}$ & {$[22]$} & sweet variety \\
\hline $\begin{array}{l}\text { Star apple fruit } \\
\text { (Chrysophillum albidum) }\end{array}$ & $1.14 \mathrm{mg} / \mathrm{kg}$ & [22] & very sweet variety \\
\hline Pomegranate juices & $0.13-0.37 \%$ & [37] & $\begin{array}{l}\text { Juices were analysed from Wonderful and Mollar de Elche } \\
\text { varieties of pomegranates. A third juice, referenced as } \\
\text { "Coupage" was evaluated, consisting of a 1:1 mix of } \\
\text { Wonderful and Mollar de Elche }\end{array}$ \\
\hline Carrot & $0.051 \mathrm{ppm}$ & \multirow{7}{*}[38]{} & \multirow{7}{*}{$\begin{array}{l}\text { Concentration of p-cymene in headspace }(0.25 \mathrm{~L}) \text { collected } \\
\text { from samples }\end{array}$} \\
\hline Pine needle & $0.003 \mathrm{ppm}$ & & \\
\hline Tangerine & $0.009 \mathrm{ppm}$ & & \\
\hline Tangerine peel & $0.408 \mathrm{ppm}$ & & \\
\hline Strawberry & $0.006 \mathrm{ppm}$ & & \\
\hline Sepals of strawberry & 0.003 ppm & & \\
\hline Orange juice & $0.0003 \mathrm{ppm}$ & & \\
\hline
\end{tabular}

\section{Bioavailability and Synthesis}

One of the major limitations of p-cymene for pharmaceutical applications is its short half-life [16]. p-Cymene is rapidly absorbed into the circulation system (time of maximum concentration, $\mathrm{T} \max =0.33 \pm 0.11 \mathrm{~h}$ ) following oral administration of essential oil from Chenopodium ambrosioides L., and it is also eliminated rapidly in vivo, as indicated by its elimination half-life $(\mathrm{T} 1 / 2=0.44 \pm 0.07 \mathrm{~h}$ ) [39]. The mean plasma concentration vs time profile of $\mathrm{p}$-cymene shows a double-peak which might be due to distribution, reabsorption, enterohepatic circulation, and interaction with multiple compounds present in formula [39].

In view of this short half-life, possible drug delivery systems for p-cymene have been studied [40]. Martins et al. [41] successfully encapsulated thymol and p-cymene within polylactide microparticles in order to protect these active agents and to provide a controlled release.

Due to industrial interest in p-cymene in the synthesis of pesticides, fungicides, perfumes, fragrances and as a starting material for the synthesis of $\mathrm{p}$-cresol, which is in turn used in the production of antioxidants like butylated hydroxytoluene (BHT) [42], the synthesis of p-cymene has been the target of several studies. According to Kamitsou et al. (2014) [43], p-cymene is conventionally produced by the Friedel-Crafts alkylation of toluene with isopropanol, or of benzene with methyl or isopropyl halides. The catalysts of these reactions are generally solutions of $\mathrm{HCl}$ acid with $\mathrm{AlCl}_{3}, \mathrm{BF}_{3}$ or $\mathrm{H}_{2} \mathrm{SO}_{4}$. However, this presents several limitations: (i) they use highly toxic substances (benzene, toluene and acids); (ii) problems with corrosion and disposal due to the use of acids; (iii) the separation of 
reagents is difficult and time consuming, as it takes place in a liquid phase by means of a batch reactor; (iv) significant amounts of o- and m-cymene are produced. Thus, alternatives for the production of p-cymene have been investigated. Alsalme et al. [44] studied the production of p-cymene through the isomerisation of gas phase $\alpha$-pinene above solid heteropoly acid catalysts at $200{ }^{\circ} \mathrm{C}$ and ambient pressure in a fixed-bed continuous flow reactor, while Al-Wadaani et al. [45] studied the production of p-cymene from $\alpha$-pinene through a one-step dehydroisomerisation using $\mathrm{Zn}(\mathrm{II})-\mathrm{Cr}(\mathrm{III})$ mixed oxide as a possessing acid. Another alternative could be to use $\alpha$-limonene, an economic by-product of the orange juice production and paper industry. Kamitsou et al. (2014) [43] found that titanium oxide was a very good catalyst of this reaction at $300{ }^{\circ} \mathrm{C}$ and at atmospheric pressure. In a study carried out by Dávila et al. [46], the production of p-cymene and pectin from orange peel was evaluated from a process, economic, and environmental point of view and it was marked as a possible way to increase the added value of essential oils from orange peel.

\section{Spectrum of Activity}

\subsection{Antibacterial Activity}

In 2013 Hashemi et al. [47] tested essential oils and methanolic extracts of Echinophora platyloba D.C for in vitro antibacterial activity against certain pathogenic bacteria present in food. The major component of these essential oils and methanolic extract was o-cymene $(26.51 \%$ and $28.66 \%$ respectively). Listeria monocytogenes and Staphylococcus aureus were the most affected by both essential oils (minimum inhibitory concentration (MIC): 6250 and 12,500 ppm respectively) and methanolic extract (MIC: 25,000 ppm); of the Gram-negative strains tested, Escherichia coli was inhibited at a MIC value of 50,000 ppm by essential oil, while methanolic extract showed no antibacterial activity. Salmonella typhimurium was not inhibited by any compounds. In 2014 Bukvički et al. [48] studied the in vitro activity of Satureja horvatii oil against some Gram-positive and Gram-negative bacteria and yeast strains. The main component of $S$. horvatii was p-cymene $(33.14 \%)$ followed by thymol $(26.11 \%)$. The MIC against bacteria ranged from $0.03 \mathrm{mg} / \mathrm{mL}$ for E. coli and S. typhimurium to $0.57 \mathrm{mg} / \mathrm{mL}$ for L. monocytogenes. Among yeasts, MIC ranged from $0.56 \mathrm{mg} / \mathrm{mL}$ (Pichia membranaefaciens) to $2.23 \mathrm{mg} / \mathrm{mL}$ (Zygosacharomyce bailii and Aureobasidium pullulans). Another study [49] investigated the essential oil of Glossogyne tenuifolia for antimicrobial activity in vitro and food systems, and its individual compounds (including $\mathrm{p}$-cymene) against certain common food pathogens. $\mathrm{p}$-Cymene was found to be the most common compound in this oil. A minimal bactericidal concentration equal to $12 \mathrm{mg} / \mathrm{mL}$ of p-cymene completely inhibited E. coli O157:H7, Vibrio parahaemolyticus, L. monocytogenes, and S. enterica. S. aureus and Streptococcus mutans showed a minimal microbicidal concentration of $6 \mathrm{mg} / \mathrm{mL}$, while S. sanguinis was inactivated by a concentration of $3 \mathrm{mg} / \mathrm{mL}$ of p-cymene. The study also investigated the synergistic interactions of the compounds found to be most active (4-terpineol, linalool, $\alpha$-terpineol and p-cymene) against the same pathogens. p-Cymene, in combination with these other molecules, showed additive effects against S. enterica, S. aureus, S. sanguinis and S. mutans, with a fractional inhibitory concentration index (FICi) of 1 for all associations, while against $E$. coli O157:H7, L. monocytogenes and V. parahaemolyticus the components showed indifferent interaction with a FIC value of 1.5. However, p-cymene was not found to be the cause of the antimicrobial activity of this essential oil.

The antibacterial activity of carvacrol and p-cymene (a precursor of carvacrol) was studied against the foodborne microorganism $V$. cholerae to evaluated the potential use of these compounds as preservative agents. Carvacrol showed a good inhibitory effect against $V$. cholerae, while p-cymene does not demonstrate this activity. However it is interesting to note that p-cymene can enhance the inhibitory effects of carvacrol when the two compounds are used together. The synergistic in vitro effect of p-cymene plus carvacrol could suggest the possible use of the combination in inhibiting $V$. cholerae and other foodborne pathogens in food [50]. 
Another study [51] demonstrated that Origanum dictamnus essential oil and its main constituents (carvacrol 52.2\%, $\gamma$-terpinene 8.4\%, p-cymene 6.1\%, linalool 1.4\% and caryophyllene $1.3 \%$ ) were active against common food spoilage and pathogen strains. Against S. enteritidis, E. coli, S. aureus and S. epidermidis, p-cymene was the least active compound with MICs of $0.527 \%(\mathrm{v} / \mathrm{v}), 0.492 \%(\mathrm{v} / \mathrm{v})$, $0.598 \%(\mathrm{v} / \mathrm{v})$ and $0.608 \%(\mathrm{v} / \mathrm{v})$ each, with the most active being carvacrol.

Andrade-Ochoa et al. (2015) [52] investigated the antimycobacterial effects of various essential oils including p-cymene, thymol and carvacrol against Mycobacterium tuberculosis and M. bovis. p-Cymene was found to be the terpene with lowest antimycobacterial activity (MIC of $91.66 \mu \mathrm{g} / \mathrm{mL}$ for both M. bovis and M. tuberculosis), while thymol and carvacrol were the most active terpenes (thymol MICs of $0.78 \mu \mathrm{g} / \mathrm{mL}$ for M. tuberculosis and $2.02 \mu \mathrm{g} / \mathrm{mL}$ for M. bovis; carvacrol MICs of $2.02 \mu \mathrm{g} / \mathrm{mL}$ for M. tuberculosis and $5.20 \mu \mathrm{g} / \mathrm{mL}$ for M. bovis). p-Cymene and the other components of Monarda punctata essential oil were investigated for antibacterial activity targeting E. coli and some common respiratory pathogens [53]. p-Cymene, thymol and limonene were the major compounds of M. punctata essential oil. S. pyogenes, methicillin-resistant S. aureus (MRSA) and Haemophilus influenzae were the most susceptible strains showing lowest MIC values, while $S$. pneumoniae and E. coli were the most resistant bacteria.

In the study of Patil et al. [54], the chemical composition of the essential oils from the two Indian spices Cuminum cyminum (cumin) and Trachyspermum ammi (ajowan) has been determined by gas chromatography-mass spectrometry. The major chemical components detected were cuminaldehyde and 2-caren-10-al in the cumin essential oil, while p-cymene and thymol were found in ajowan essential oil. The antibacterial activity of these essential oils was evaluated against several Gram-positive and Gram-negative bacteria. Both the oils exhibited a strong antibacterial effect against most of the tested bacteria. Furthermore, cumin and ajowan oils demonstrated remarkable antibacterial activity against Salmonella enterica seroval Typhi. Ajowan oil exhibited a wider spectrum of activities against both the Gram-positive and Gram-negative organisms when compared with cumin [54]. An antibacterial activity of oregano essential oil against planktonic S. aureus and S. epidermidis, including methicillin resistant strains has been described by Nostro et al. [55].

\subsection{Antifungal Activity}

In 2013, Aznar and colleagues [56] studied the growth of Candida lusitaniae under various concentrations of natural compounds including carvacrol, thymol, and cymene in order to evaluate their possible use as food preservatives. The growth rate of $C$. lusitaniae was reduced in the presence of these molecules, while the lag time increased with increasing concentrations. All molecules tested inhibited yeast growth for at least 21 days at a concentration of $1 \mathrm{mmol} / \mathrm{L}$. The delay increased up to 45 days in the presence of cymene. Cymene was more effective than thymol and carvacrol at higher concentrations $(0.2-0.5 \mathrm{mmol} / \mathrm{L})$. In the same year, another research group [57] studied the effect of some herbal essential oils against ovine dermatophytes. Thymus serpillum and Origano vulgare essential oils showed the lowest MIC $(0.1 \%$ and $0.5 \%)$, while p-cymene, that was one of the main component of these essential oils, showed no specific anti-dermathophytes activity with a MIC and a minimum fungicidal concentration (MFC) $>8 \%$.

p-Cymene does not seem to have activity against filamentous fungi; the results of a study conducted by de Lira Mota et al. (2012) [58] showed that p-cymene does not possess antifungal activity against Rhizopus oryzae (MICs: $>1024 \mu \mathrm{g} / \mathrm{mL}$ for all strains). p-Cymene also showed no antifungal activity against Aspergillus niger (MIC: $>300 \mu \mathrm{L} / \mathrm{mL}$ ) [59].

Regarding the antifungal activity of essential oils containing high percentage of cymene, in 2014 Kedia and colleagues [60], studied the antifungal properties of Ciminum cymininunm L. seed essential oil against $A$. flavus strain LHP(C)-D6. The chemical characterization by gas chromatography/mass spectrometry (GC/)MS) analysis of these seed oil revealed the presence of many compounds, among them the most represented was cymene (47.08\%). This essential oil showed high antifungal activity, indeed the MIC that inhibited the growth of A. flavus was $0.6 \mu \mathrm{g} / \mathrm{mL}$, while the fungicidal concentration 
was $0.9 \mu \mathrm{g} / \mathrm{mL}$. Given the low MIC values, the authors suggested that this essential oil could be useful for the permanent disinfection of food borne fungi from food items. Other authors [51] also evaluated the activity of Origanum dictamnus essential oil (containing 6.07\% of p-cymene), against Saccharomyces cerevisiae and $A$. niger, microbes used as model system in food spoilage. The results obtained with the disk diffusion method, indicated that both fungi tested were sensitive to this essential oil.

\subsection{Antiparasitic Activity}

In 2013, a research group [60] investigated the in vitro antiparasitic activity of a series of chelating cationic ruthenium(II)-arene complexes on thiosemicarbazone scaffolds against two Plasmodium falciparum strains (chloroquine-sensitive and chloroquine resistant) and against a Trichomonas vaginalis strain. The investigation showed that complexes containing the p-cymene were more active than those containing benzene. In 2014, an investigation conducted by Kpadonou Kpoviessi (2014) [61] studied the antitrypanosomal and antiplasmodial activities in vitro of essential oils and crude extracts from Ocimum gratissimum against Trypanosoma brucei brucei and P. falciparum. p-Cymene represents about $31.53 \%$ of the essential oil extracted from aerial parts of 0 . gratissimum harvested in the pre-flowering stage and $28.08 \%$ of those in the full flowering stage, and showed moderate activity in this case (sample concentration provided death of $50 \%$ of parasites, with a half maximal inhibitory concentration (IC50) of $76.32 \mu \mathrm{g} / \mathrm{mL})$.

\subsection{Anti-Biofilm Activity}

As an extension of the work on the efficacy of the oregano essential oil components against planktonic methicillin-resistant staphylococci [55], it has been demonstrated that these substances are able to inhibit the growth of staphylococcal preformed biofilms, and even to interfere with biofilm formation during planktonic growth [62]. The oregano oil is characterized principally by carvacrol and thymol and by their two precursors, c-terpinene and p-cymene [63]. The antimicrobial activity of oregano oil is mostly attributed to the action of its components carvacrol and thymol, which exhibited significant bactericidal activity when tested separately [64].

By scanning electron microscopy (SEM) analysis, a very high inhibitory effect by Eucalyptus essential oil on biofilm formation by Proteus mirabilis on urinary catheters was demonstrated. Cymene is present among the major fractions of Eucalyptus essential oil, to which the anti-biofilm properties were ascribed [65]. Besides the anti-biofilm effect on urinary catheters, Eucalyptus oil has been demonstrated to reduce biofilms formed by S. epidermidis on the skin [66].

Oral candidiasis is an opportunistic infection of the oral cavity, which usually occurs in the immunocompromised individuals. The effects of Satureja hortensis L. essential oil on the planktonic form, biofilm production, and mature biofilms of C. albicans from buccal lesions of HIV+ individuals have been investigated. This essential oil has thymol, gamma-terpinen, carvacrol and p-cymene among its most abundant constituents. The biofilm formation by $C$. albicans on polystyrene was drastically reduced by Satureja hortensis L. essential oil. At sub-MIC concentration, SEM analysis revealed loosening of cells, deformity of three dimensional structures of biofilms, and shrinkage in cell membranes of sessile cells. These observations suggest a potential exploitation of this oil as a natural anti-biofilm product in the treatment of buccal cavity lesions caused by C. albicans [67]. Analogously, the work of Khan et al. demonstrated an attenuation in the biofilm production by C. albicans (C. albicans 04 and C. albicans SC5314) in the presence of essential oils. Biofilm production was reduced maximally by thymol [68].

Very recently, it has been observed that p-cymene reduces biofilm formation in Burkholderia xenovorans. This effect has been ascribed to the accumulation of $\mathrm{p}$-cymene in bacterial membrane and to the changes in the membrane structure induced by this aromatic compound [69]. 


\subsection{Anti-Inflammatory Activity}

In addition to the antibacterial and anti-biofilm activities of terpenes, in particular of p-cymene, an anti-inflammatory activity has also been proved. Anti-inflammatory compounds, both steroidal and nonsteroidal, are the major routes for the treatment of inflammatory disorders. However, the use of synthetic anti-inflammatory molecules is associated with serious common side effects, including gastric irritation, ulceration, bleeding, renal failure and hepatic damage [70,71].

In recent years, phytochemicals derived from plants have gained increased attention due to their safe toxicological profiles in respect to non-steroidal and steroidal drugs and their protective effects [70]. The recent advances in the preparation and characterization of nanosized vectors able to release phytochemicals endowed with anti-inflammatory activity and the range of new delivery technologies are presented and discussed in the cited review [72].

\subsection{Anti-Infective and Anti-Inflammatory Biomaterials}

Phytochemicals have promising potential to prevent and/or treat inflammatory and biofilm-associated diseases. Drug delivery systems based on nanomaterials can potentiate the solubility and stability of phytochemicals, improve their absorption, protect them from premature enzymatic degradation or metabolism in the body, and extend their circulation time, limiting their side effects.

A comprehensive review on nanosized delivery systems for plant drugs has been presented by Bonifácio et al. [73].

Different kind of nanomaterials have been proposed to be conjugated with monoterpenes, such as metals (particularly silver nanoparticles), polymers (mainly resorbable polymers), and chitosan (the most important derivative of chitin, a natural polymer obtained from marine crustacean shell).

The "green" synthesis of metal nanoparticles arouses great interest due to the advances in ecofriendly technologies in material science. An interesting example is the one step synthesis of antibacterial silver nano/microparticles using extract of Trachyspermum ammi. The extract, containing p-cymene together with thymol and $\gamma$-terpinene, was found to be a valuable agent for the formation of biocompatible silver nanoparticles. The obtained nanoparticles were triangular shaped and smaller than $100 \mathrm{~nm}$ [74].

Besides p-cymene, also carvacrol has been studied for its antibacterial activity when conjugated with nanomaterials. Carvacrol-chitosan nanoparticles, exhibiting a spherical shape with an average diameter of 4-80 nm, have shown antimicrobial activity against S. aureus, Bacillus cereus and E. coli [75].

A ionic amphiphilic chitosan derivative obtained by the interaction between chitosan and oleic acid has been recently proposed to stabilize the nanoemulsion of the essential oil Cymbopogon citratus (DC.) Stapf (Lemongrass), thus improving its delivery. The combination of spontaneous emulsification process with chitosan oleate amphiphilic properties resulted in: (i) stable dispersion of a few hundred nanometer droplets; (ii) maintenance or improvement in the essential oil antimicrobial activity towards nine bacterial and ten fungal strains; (iii) biocompatibility of the nanoemulsion (cytotoxicity test performed on four different cell lines) [76].

Phytochemical-based polymers can find applications as biomedical materials and, more importantly, they greatly contribute to the new concept of sustainable polymer chemistry. In particular, the design and preparation of terpene-based polymers involve different chemical strategies and a wide variety of polymerization techniques [77].

Carvacrol has attracted attention for its ability to promote the disruption of microbial biofilm. By encapsulation of carvacrol in poly(dl-lactide-co-glycolide (PLGA) resorbable nanocapsules a suitable drug delivery system has been obtained, representing a starting point for new therapeutic strategies against biofilm-associated infections [78].

Also, poly(lactic acid) nanofibrous resorbable membranes produced by electrospinning and solution blow spinning (SBS) have been used as carriers of an antimicrobial natural plant oil such as linalool [79], a scented terpene alcohol found in many flowers and spice plants (Lavender, Coriander, Basil). 
A more complex system has been described, consisting in hybrid poly(lactic acid) (PLA) fibres loaded with highly crystalline cellulose nanowhiskers (filamentary crystal with cross sectional diameter ranging from 1 to $100 \mathrm{~nm}$ ) by a novel solution blow spinning method. Carvacrol was incorporated as antimicrobial agent, demonstrating a biocide effect against L. monocytogenes [80]. Carvacrol has been also loaded on polyhydroxybutyrate nanoparticles exhibiting an antimicrobial activity against E. coli [81].

In a very recent study, clove oil, together with hydrolysed chitosan and turmeric powder, was used to formulate an antimicrobial coating for the polyethylene terephthalate (PET) and polyamide (Nylon 6) surgical sutures, with the aim of preventing wound site infections. Interestingly, the coated sutures showed antibacterial activity against $S$. aureus and even a (slight) improvement of tensile and knot strength properties. [82].

The use of antibacterial biomaterials, biomaterials surfaces, and coatings based on natural bactericidal substances produced by plants is a new fascinating approach. Over millions of years, living organisms have developed multifaceted and successful strategies to efficiently prevent the colonisation of their surfaces by pathogens. These strategies can be mimicked to create a new generation of bio-inspired antibacterial and biofilm-resistant surfaces [83].

\subsection{Mechanism of Action}

In a study conducted by Ultee et al. [84], the modes of action of cymene and carvacrol were investigated using B. cereus, a food borne pathogen, as a model. The study investigated the effects of natural compounds on liposomal membrane expansion, looking into their influence on membrane potential, changes in intracellular $\mathrm{pH}$, influences on the amount of ATP, and effects on the growth of B. cereus. Carvacrol and cymene added to liposomes both caused an expansion of the cytoplasmic membrane, but the degree of expansion caused by cymene was 2.7 times greater than the expansion due to carvacrol. Both molecules induced a reduction in membrane potential, but the cymene concentrations required were higher than those of carvacrol. Cymene had no effect on the $\mathrm{pH}$ gradient across the membrane at concentrations from $0.5 \mathrm{mM}$ to $2 \mathrm{mM}$, while at a concentration of $1 \mathrm{mM}$, carvacrol was able to eliminate the $\mathrm{pH}$ gradient. Moreover, it was shown that concentrations of 1 and $2.4 \mathrm{mM}$ of cymene had no effect on the extra- and intra-cellular ATP levels. Conversely, carvacrol caused a decrease in intracellular ATP levels. Interestingly, it was demonstrated that the hydroxyl group present in carvacrol plays a vital part in exerting its antimicrobial effects. Carvacrol was able to inhibit B. cereus growth at concentrations of $0.75 \mathrm{mM}$ and above, while cymene, lacking in the hydroxyl group, was unable to inhibit strain growth from $0.5 \mathrm{mM}$ to $10 \mathrm{mM}$. The antimicrobial activity was affected by the presence, or lack of, the hydroxyl group rather than its position in the benzene ring.

More recently, Cristani et al. (2007) [85] evaluated the damage caused by some monoterpenes such as carvacrol and its precursor p-cymene, on biomembranes of E. coli and S. aureus. This research suggests that the antimicrobial effects of p-cymene and carvacrol could be due to a perturbation of lipids in the bacterial membrane. The ways in which carvacrol and p-cymene impact protein synthesis and cell motility in E. coli O157:H7 strain were also recently investigated by Burt and team [86]. The presence of sublethal concentrations of carvacrol $(1 \mathrm{mM})$ overnight led to increases in heat shock protein 60 and decreases in the synthesis of flagellin, producing nonmotile bacteria, while p-cymene had an insignificant effect on the synthesis of proteins. E. coli O157:H7 cells in the exponential phase were subjected to a 3-h treatment of increasing concentrations of p-cymene and carvacrol, which yielded an increase in HSP 60 levels and a decrease in motility which correlated with the increased concentrations used. However, the flagella were not shed.

Li et al. (2014) [53], studied the morphological changes induced by treatment, with p-cymene and other essential oils of Monarda punctata, of the bacterial architecture of S. pyogenes and MRSA using scanning electron microscopy, also studying the generation of ROS in the treated cells. The SEM observation showed that damage induced by treatment with essential oils was dose-dependent; over $95 \%$ of bacterial cells were killed with a treatment time of $12 \mathrm{~h}$ at a concentration of $90 \mu \mathrm{g} / \mathrm{mL}$ of 
essential oil. The treated bacterial cells appeared swollen after $12 \mathrm{~h}$, while no change in morphological structure was observed in untreated cells. Elevated levels of ROS were detected and measured after $4 \mathrm{~h}$ of treatment with essential oil.

\section{Conclusions}

In recent years, with the increasing incidence of antimicrobial resistance, many studies have been carried out on the antimicrobial activity of bioactive compounds. Natural compounds extracted from various plants, food and beverages, could provide possible alternatives to standard antimicrobial agents. It is well known that some commercial essential oils, especially those extracted from thyme or oregano, have antimicrobial capacities against certain food-borne bacteria. These properties are often attributed to their primary bioactive constituents.

This review summarizes the studies describing the antimicrobial activity monoterpenes, especially p-cymene, published in the past five years, either alone or as a main constituent of plant extracts. Most studies evaluated the antimicrobial activity of some essential oils and or plant extracts containing various phytochemicals, including p-cymene, but only few researches have analysed the antimicrobial activity of p-cymene alone.

Based on literature data, we can conclude that p-cymene is one of the major constituents of the extracts and essential oils obtained from many medicinal and food plants. p-Cymene uses as antimicrobial agent (especially in topical application for symptomatic treatment of common skin disorders, treatment of wounds, and vaginitis) are well described in pharmacopoeias and in traditional medicine, but are often unsupported by clinical data.

The literature data reported in this review show that when used alone, $\mathrm{p}$-cymene is not the main compound conferring the antimicrobial activity of essential oils and/or plant extracts. In particular, several authors demonstrated that p-cymene is less efficient as an antimicrobial agent than its derivative carvacrol. Nevertheless, based on literature reports, we can highlight that p-cymene enhances the activity of other antimicrobial agents through synergism, antagonism and additive effects. Because of the potential cytotoxicity of several antimicrobial substances, especially found in essential oils, the finding that $\mathrm{p}$-cymene improves the antimicrobial properties of other substances, such as i.e. carvacrol, 4-terpineol, and nisin [87-90] could be of great interest, especially in cosmetic and pharmaceutical fields, since p-cymene addition could reduce the concentration of other antimicrobial compounds. Regardless, the interaction among essential oil individual components and p-cymene requires further research to elucidate the mechanism underlying this biological activity. In addition, the evaluation of data from the literature highlights that $\mathrm{p}$-cymene can reduce biofilm formation. This aspect needs further study, since biofilm formation is important for the persistence of pathogens under environmental conditions, inducing colonization in the host by microorganisms and increasing their resistance to antimicrobial agents.

Microbial contamination of food products is an important problem, especially in developing countries. For the use of monoterpenes, and especially p-cymene, in food products, data from the literature showed that essential oils and plant extracts, containing various phytochemicals including p-cymene, can be used as a fungicide or herbicide, as well as an insecticide. Further studies are needed to elucidate the role of $\mathrm{p}$-cymene and to understand its biological activity for the purpose of developing new natural antiseptics for the food industry.

Finally, p-cymene appears a promising phytochemical to be incorporated into advanced polymers for anti-infective and anti-inflammatory biomaterials and nanomaterials.

Concluding, we advise ongoing focus on toxicological studies and clinical trials on a range of infectious diseases, aiming to evaluate the efficacy of p-cymene, both alone and as a constituent of plant extracts, and to determine a safe and efficient dose. 
Author Contributions: A.M., S.M.N. and M.D. conceived the review topics; A.M. and A.J.T.S. wrote the part on chemistry and sources; A.M., R.B. and A.S.S., wrote the part on bioavailability and antimicrobial activities; S.F.N., M.I. and N.J.J. wrote the introduction and conclusions. I.S. revised the manuscript. C.R.A. wrote the part on anti-biofilm and anti-inflammatory activities and on biomaterials, and revised the final version of the manuscript. All authors read and approved the final version of the review.

Conflicts of Interest: The authors declare no conflict of interest.

\section{References}

1. Crozier, A.; Clifford, M.N.; Ashihara, H. Plant Secondary Metabolites: Occurrence, Structure and Role in the Human Diet; Blackwell Publishing Ltd.: Oxford, UK, 2006; ISBN 13978-1-4051-2509-3.

2. Daglia, M. Polyphenols as antimicrobial agents. Curr. Opin. Biotechnol. 2012, 23, 174-181. [CrossRef] [PubMed]

3. Katsori, A.M.; Hadjipavlou-Litina, D. Coumarin derivatives: An updated patent review (2012-2014). Expert Opin. Ther. Pat. 2014, 24, 1323-1347. [CrossRef] [PubMed]

4. Nabavi, S.F.; Di Lorenzo, A.; Izadi, M.; Sobarzo-Sánchez, E.; Daglia, M.; Nabavi, S.M. Antibacterial effects of cinnamon: From farm to food, cosmetic and pharmaceutical industries. Nutrients 2015, 7, 7729-7748. [CrossRef] [PubMed]

5. Nabavi, S.M.; Marchese, A.; Izadi, M.; Curti, V.; Daglia, M.; Nabavi, S.F. Plants belonging to the genus Thymus as antibacterial agents: From farm to pharmacy. Food Chem. 2015, 173, 339-347. [CrossRef] [PubMed]

6. Philis, J.G. The S1 $\leftarrow$ S0 spectrum of jet-cooled p-cymene. Spectrochim. Acta Mol. Biomol. Spectrosc. 2005, 61, 1239-1241. [CrossRef] [PubMed]

7. De Oliveira, T.M.; de Carvalho, R.B.F.; da Costa, I.H.F.; de Oliveira, G.A.L.; de Souza, A.A.; de Lima, S.G.; de Freitas, R.M. Evaluation of p-cymene, a natural antioxidant. Pharm. Biol. 2015, 53, 423-428. [CrossRef] [PubMed]

8. Quintans-Júnior, L.; Moreira, J.C.; Pasquali, M.A.; Rabie, S.M.; Pires, A.S.; Schröder, R.; Rabelo, T.K.; Santos, J.P.; Lima, P.S.; Cavalcanti, S.C.; et al. Antinociceptive Activity and Redox Profile of the Monoterpenes (+)-Camphene, p-Cymene, and Geranyl Acetate in Experimental Models. ISRN Toxicol. 2013, 2013, 459530.

9. Zhong, W.; Chi, G.; Jiang, L.; Soromou, L.W.; Chen, N.; Huo, M.; Guo, W.; Deng, X.; Feng, H. p-Cymene modulates in vitro and in vivo cytokine production by inhibiting MAPK and NF- $\mathrm{BB}$ activation. Inflammation 2013, 36, 529-537. [CrossRef] [PubMed]

10. Bonjardim, L.R.; Cunha, E.S.; Guimarães, A.G.; Santana, M.F.; Oliveira, M.G.; Serafini, M.R.; Araújo, A.A.; Antoniolli, Â.R.; Cavalcanti, S.C.; Santos, M.R.; et al. Evaluation of the anti-inflammatory and antinociceptive properties of p-cymene in mice. Z. Naturforsch. C 2012, 67, 15-21. [CrossRef] [PubMed]

11. De Santana, M.F.; Guimarães, A.G.; Chaves, D.O.; Silva, J.C.; Bonjardim, L.R.; de Lucca Júnior, W.; Ferro, J.N.; Barreto Ede, O.; dos Santos, F.E.; Soares, M.B.; et al. The anti-hyperalgesic and anti-inflammatory profiles of p-cymene: Evidence for the involvement of opioid system and cytokines. Pharm. Biol. 2015, 53, 1583-1590. [CrossRef] [PubMed]

12. Kaluđerović, G.N.; Krajnović, T.; Momcilovic, M.; Stosic-Grujicic, S.; Mijatović, S.; Maksimović-Ivanić, D.; Hey-Hawkins, E. Ruthenium(II) p-cymene complex bearing 2,2'-dipyridylamine targets caspase 3 deficient MCF-7 breast cancer cells without disruption of antitumor immune response. J. Inorg. Biochem. 2015, 153, 315-321. [CrossRef] [PubMed]

13. Li, J.; Liu, C.; Sato, T. Novel Antitumor Invasive Actions of p-Cymene by Decreasing MMP-9/TIMP-1 Expression Ratio in Human Fibrosarcoma HT-1080 Cells. Biol. Pharm. Bull. 2016, 39, 1247-1253. [CrossRef] [PubMed]

14. Păunescu, E.; Nowak-Sliwinska, P.; Clavel, C.M.; Scopelliti, R.; Griffioen, A.W.; Dyson, P.J. Anticancer Organometallic Osmium(II)-p-cymene Complexes. ChemMedChem 2015, 10, 1539-1547. [CrossRef] [PubMed]

15. Joglekar, M.M.; Panaskar, S.N.; Arvindekar, A.U. Inhibition of advanced glycation end product formation by cymene-A common food constituent. J. Funct. Foods 2014, 6, 107-115. [CrossRef]

16. Quintans, J.D.S.S.; Menezes, P.P.; Santos, M.R.; Bonjardim, L.R.; Almeida, J.R.; Gelain, D.P.; Quintans-Júnior, L.J. Improvement of p-cymene antinociceptive and anti-inflammatory effects by inclusion in $\beta$-cyclodextrin. Phytomedicine 2013, 20, 436-440. [CrossRef] [PubMed]

17. CAS 99-87-6. Available online: https://chem.nlm.nih.gov/chemidplus/name/p-cymene (accessed on 18 May 2017). 
18. Kummer, R.; Estevão-Silva, C.F.; Bastos, R.L.; Grespan, R.; de Souza Silva-Comar, F.M.; Silva, E.L.; Spironello, R.A.; Rocha, B.A.; Bersani-Amado, C.A.; Cuman, R.K.N. Effect of p-cymene on chemotaxis, phagocytosis and leukocyte behaviors. Int. J. Appl. Res. Nat. Prod. 2015, 8, 20-27.

19. Food and Drug Administration. Substances Generally Recognized as Safe Food Additives Permitted for Direct Addition to Food for Human Consumption. C.F.R 2006. Available online: https:/ / www.accessdata. fda.gov/scripts/cdrh/cfdocs/cfCFR/CFRSearch.cfm?fr=172.515 (accessed on 15 May 2017).

20. Barbosa, R.L.; Santos, J.H.; Cunha, P.S.; Quintans-Júnior, L.J.; Bonjardim, L.R.; de Souza Araújo, A.A. Vasorelaxant activity of p-cymene in superior mesenteric artery of rats. FASEB J. 2013, 27.

21. Silva, M.T.; Ribeiro, F.P.; Medeiros, M.A.; Sampaio, P.A.; Silva, Y.M.; Silva, M.T.; Quintans, J.S.; Quintans-Júnior, L.J.; Ribeiro, L.A. The vasorelaxant effect of p-Cymene in rat aorta involves potassium channels. Sci. World J. 2015, 2015, 458080. [CrossRef] [PubMed]

22. Lasekan, O.; Khatib, A.; Juhari, H.; Patiram, P.; Lasekan, S. Headspace solid-phase microextraction gas chromatography-mass spectrometry determination of volatile compounds in different varieties of African star apple fruit (Chrysophillum albidum). Food Chem. 2013, 141, 2089-2097. [CrossRef] [PubMed]

23. Beaulieu, J.C.; Stein-Chisholm, R.E. HS-GC-MS volatile compounds recovered in freshly pressed 'Wonderful'cultivar and commercial pomegranate juices. Food Chem. 2016, 190, 643-656. [CrossRef] [PubMed]

24. Ribeiro-Santos, R.; Andrade, M.; de Melo, N.R.; dos Santos, F.R.; de Araújo Neves, I.; de Carvalho, M.G.; Sanches-Silva, A. Biological activities and major components determination in essential oils intended for a biodegradable food packaging. Ind. Crops Prod. 2017, 97, 201-210. [CrossRef]

25. World Health Organization. WHO Monographs on Selected Medicinal Plants; WHO: Geneva, Switzerland, 1999; Volume 2, pp. 103-113, ISBN 924-1-54-517-8.

26. World Health Organization. WHO Monographs on Selected Medicinal Plants; WHO: Geneva, Switzerland, 1999; Volume 3, pp. 33-41, ISBN 924-1-54-517-8.

27. World Health Organization. WHO Monographs on Selected Medicinal Plants; WHO: Geneva, Switzerland, 1999; Volume 4, pp. 167-178, ISBN 924-1-54-517-8.

28. Cavalli, J.F.; Tomi, F.; Bernardini, A.F.; Casanova, J. Combined analysis of the essential oil of Chenopodium ambrosioides by GC, GC-MS and 13C-NMR spectroscopy: Quantitative determination of ascaridole, a heat-sensitive compound. Phytochem. Anal. 2004, 15, 275-279. [CrossRef] [PubMed]

29. Ahmad, M.M.; Rehman, S.U.; Iqbal, Z.; Anjum, F.M.; Sultan, J.I. Genetic variability to essential oil composition in four citrus fruit species. Pak. J. Bot. 2006, 38, 319-324.

30. Asbaghian, S.; Shafaghat, A.; Zarea, K.; Kasimov, F.; Salimi, F. Comparison of volatile constituents, and antioxidant and antibacterial activities of the essential oils of Thymus caucasicus, T. kotschyanus and T. vulgaris. Nat. Prod. Commun. 2011, 6, 137-140. [PubMed]

31. Bourgou, S.; Rahali, F.Z.; Ourghemmi, I.; Saïdani Tounsi, M. Changes of peel essential oil composition of four Tunisian citrus during fruit maturation. Sci. World J. 2012, 2012, 528593. [CrossRef] [PubMed]

32. Jantamas, S.; Matan, N.; Matan, N. Effect of tangerine oil against Aspergillus niger identified from raw and boron treated rubberwood. IJESD 2013, 4, 408-411. [CrossRef]

33. Bentayeb, K.; Vera, P.; Rubio, C.; Nerín, C. The additive properties of Oxygen Radical Absorbance Capacity (ORAC) assay: The case of essential oils. Food Chem. 2014, 148, 204-208. [CrossRef] [PubMed]

34. Mechergui, K.; Jaouadi, W.; Coelho, J.P.; Khouja, M.L. Effect of harvest year on production, chemical composition and antioxidant activities of essential oil of oregano (Origanum vulgare subsp glandulosum (Desf.) Ietswaart) growing in North Africa. Ind. Crops Prod. 2016, 90, 32-37. [CrossRef]

35. Foe, F.M.C.; Nyegue, M.A.; Kamdem, S.L.S.; Essama, R.H.S.; Etoa, F. Chemical composition, antioxidant effects and antimicrobial activities of some spices' essential oils on food pathogenic bacteria. Afr. J. Biotechnol. 2016, 15, 649-656.

36. De Sousa Guedes, J.P.; da Costa Medeiros, J.A.; de Souza E Silva, R.S.; de Sousa, J.M.; da Conceição, M.L.; de Souza, E.L. The efficacy of Mentha arvensis L. and M. piperita L. essential oils in reducing pathogenic bacteria and maintaining quality characteristics in cashew, guava, mango, and pineapple juices. Int. J. Food Microbiol. 2016, 238, 183-192. [CrossRef] [PubMed]

37. Andreu-Sevilla, A.J.; Mena, P.; Martí, N.; Viguera, C.G.; Carbonell-Barrachina, Á.A. Volatile composition and descriptive sensory analysis of pomegranate juice and wine. Food Res. Int. 2013, 54, 246-254. [CrossRef]

38. Iqbal, M.A.; Kim, K.H.; Ahn, J.H. Monoterpenes released from fruit, plant, and vegetable systems. Sensors 2014, 14, 18286-18301. [CrossRef] [PubMed] 
39. Hu, X.; Chu, Y.; Ma, G.; Li, W.; Wang, X.; Mo, H.; Yin, Q.; Guo, J.; Ma, X.; Zhou, S. Simultaneous determination of ascaridole, $\mathrm{p}$-cymene and $\alpha$-terpinene in rat plasma after oral administration of Chenopodium ambrosioides L. by GC-MS. Biomed. Chromatogr. 2015, 29, 1682-1686. [CrossRef] [PubMed]

40. Serafini, M.R.; Menezes, P.P.; Costa, L.P.; Lima, C.M.; Quintans, L.J.; Cardoso, J.C.; Matos, J.R.; Soares-Sobrinho, J.L.; Grangeiro, S., Jr.; Nunes, P.S.; et al. Interaction of p-cymene with $\beta$-cyclodextrin. J. Therm. Anal. Calorim. 2012, 109, 951-955. [CrossRef]

41. Martins, I.M.; Rodrigues, S.N.; Barreiro, M.F.; Rodrigues, A.E. Release studies of thymol and p-cymene from polylactide microcapsules. Ind. Eng. Chem. Res. 2012, 51, 11565-11571. [CrossRef]

42. Sanches-Silva, A.; Cruz, J.M.; Sendón-Garcia, R.; Paseiro-Losada, P. Determination of butylated hydroxytoluene in food samples by high-performance liquid chromatography with ultraviolet detection and gas chromatography/mass spectrometry. J. AOAC Int. 2007, 90, 277-283. [PubMed]

43. Kamitsou, M.; Panagiotou, G.D.; Triantafyllidis, K.S.; Bourikas, K.; Lycourghiotis, A.; Kordulis, C. Transformation of $\alpha$-limonene into p-cymene over oxide catalysts: A green chemistry approach. Appl. Catal. A Gen. 2014, 474, 224-229. [CrossRef]

44. Alsalme, A.; Kozhevnikova, E.F.; Kozhevnikov, I.V. $\alpha$-Pinene isomerisation over heteropoly acid catalysts in the gas-phase. Appl. Catal. A Gen. 2010, 390, 219-224. [CrossRef]

45. Al-Wadaani, F.; Kozhevnikova, E.F.; Kozhevnikov, I.V. Zn(II)-Cr(III) mixed oxide as efficient bifunctional catalyst for dehydroisomerisation of $\alpha$-pinene to p-cymene. Appl. Catal. A Gen. 2009, 363, 153-156. [CrossRef]

46. Dávila, J.A.; Rosenberg, M.; Cardona, C.A. Techno-economic and Environmental Assessment of p-cymene and pectin production from orange peel. Waste Biomass Valoriz. 2015, 6, 253-261. [CrossRef]

47. Hashemi, M.; Ehsani, A.; Hosseini Jazani, N.; Aliakbarlu, J.; Mahmoudi, R. Chemical composition and in vitro antibacterial activity of essential oil and methanol extract of Echinophora platyloba D.C against some of food-borne pathogenic bacteria. Vet. Res. Forum 2013, 4, 123-127. [PubMed]

48. Bukvički, D.; Stojković, D.; Soković, M.; Vannini, L.; Montanari, C.; Pejin, B.; Savić, A.; Veljić, M.; Grujić, S.; Marin, P.D. Satureja horvatii essential oil: In vitro antimicrobial and antiradical properties and in situ control of Listeria monocytogenes in pork meat. Meat Sci. 2014, 96, 1355-1360. [CrossRef] [PubMed]

49. Yang, T.S.; Chao, L.K.; Liu, T.T. Antimicrobial activity of the essential oil of Glossogyne tenuifolia against selected pathogens. J. Sci. Food Agric. 2014, 94, 2965-2971. [CrossRef] [PubMed]

50. Rattanachaikunsopon, P.; Phumkhachorn, P. Assessment of factors influencing antimicrobial activity of carvacrol and cymene against Vibrio cholerae in food. J. Biosci. Bioeng. 2010, 110, 614-619. [CrossRef] [PubMed]

51. Mitropoulou, G.; Fitsiou, E.; Stavropoulou, E.; Papavassilopoulou, E.; Vamvakias, M.; Pappa, A.; Oreopoulou, A.; Kourkoutas, Y. Composition, antimicrobial, antioxidant, and antiproliferative activity of Origanum dictamnus (dittany) essential oil. Microb. Ecol. Health Dis. 2015, 26, 26543. [PubMed]

52. Andrade-Ochoa, S.; Nevárez-Moorillón, G.V.; Sánchez-Torres, L.E.; Villanueva-García, M.; Sánchez-Ramírez, B.E.; Rodríguez-Valdez, L.M.; Rivera-Chavira, B.E. Quantitative structure-activity relationship of molecules constituent of different essential oils with antimycobacterial activity against Mycobacterium tuberculosis and Mycobacterium bovis. BMC Complement. Altern. Med. 2015, 15, 332. [CrossRef] [PubMed]

53. Li, H.; Yang, T.; Li, F.Y.; Yao, Y.; Sun, Z.M. Antibacterial activity and mechanism of action of Monarda punctata essential oil and its main components against common bacterial pathogens in respiratory tract. Int. J. Clin. Exp. Pathol. 2014, 7, 7389-7398. [PubMed]

54. Patil, S.D.; Maknikar, P.P.; Wankhade, S.J.; Ukesh, C.S.; Rai, M.K. Chemical composition, antimicrobial and antioxidant activity of essential oils from cumin and ajowan. Nusant. Biosci. 2016, 8, 60-65. [CrossRef]

55. Nostro, A.; Blanco, A.R.; Cannatelli, M.A.; Enea, V.; Flamini, G.; Morelli, I.; Sudano Roccaro, A.; Alonzo, V. Susceptibility of methicillin-resistant staphylococci to oregano essential oil, carvacrol and thymol. FEMS Microbiol. Lett. 2004, 230, 191-195. [CrossRef]

56. Aznar, A.; Fernández, P.S.; Periago, P.M.; Palop, A. Antimicrobial activity of nisin, thymol, carvacrol and cymene against growth of Candida lusitaniae. Food Sci. Technol. Int. 2015, 21, 72-79. [CrossRef] [PubMed]

57. Mugnaini, L.; Nardoni, S.; Pistelli, L.; Leonardi, M.; Giuliotti, L.; Benvenuti, M.N.; Pisseri, F.; Mancianti, F. A herbal antifungal formulation of Thymus serpillum, Origanum vulgare and Rosmarinus officinalis for treating ovine dermatophytosis due to Trichophyton mentagrophytes. Mycoses 2013, 56, 333-337. [CrossRef] [PubMed] 
58. De Lira Mota, K.S.; de Oliveira Pereira, F.; de Oliveira, W.A.; Lima, I.O.; de Oliveira Lima, E. Antifungal activity of Thymus vulgaris L. essential oil and its constituent phytochemicals against Rhizopus oryzae: Interaction with ergosterol. Molecules 2012, 17, 14418-14433. [CrossRef] [PubMed]

59. Matan, N.; Matan, N.; Ketsa, S. Enhanced inhibition of Aspergillus niger on sedge (Lepironia articulata) treated with heat-cured lime oil. J. Appl. Microbiol. 2013, 115, 376-381. [CrossRef] [PubMed]

60. Kedia, A.; Prakash, B.; Mishra, P.K.; Dubey, N.K. Antifungal and antiaflatoxigenic properties of Cuminum cyminum (L.) seed essential oil and its efficacy as a preservatives in stored commodities. Int. J. Food Microbiol. 2014, 168-169, 1-7. [CrossRef] [PubMed]

61. Kpadonou Kpoviessi, B.G.; Kpoviessi, S.D.; Ladekan, E.Y.; Gbaguidi, F.; Frédérich, M.; Moudachirou, M.; Quetin-Leclercq, J.; Accrombessi, G.C.; Bero, J. In vitro antitrypanosomal and antiplasmodial activities of crude extracts and essential oils of Ocimum gratissimum Linn from Benin and influence of vegetative stage. J. Ethnopharmacol. 2014, 155, 1417-1423. [CrossRef] [PubMed]

62. Adams, M.; Li, Y.; Khot, H.; De Kock, C.; Smith, P.J.; Land, K.; Chibale, K.; Smith, G.S. The synthesis and antiparasitic activity of aryl-and ferrocenyl-derived thiosemicarbazone ruthenium(II)-arene complexes. Dalton Trans. 2013, 42, 4677-4685. [CrossRef] [PubMed]

63. Nostro, A.; Sudano Roccaro, A.; Bisignano, G.; Marino, A.; Cannatelli, M.A.; Pizzimenti, F.C.; Cioni, P.L.; Procopio, F.; Anna Blanco, A.R. Effects of oregano, carvacrol and thymol on Staphylococcus aureus and Staphylococcus epidermidis biofilms. J. Med. Microbiol. 2007, 56, 519-523. [CrossRef] [PubMed]

64. Friedman, M.; Henika, P.R.; Mandrell, R.E. Bactericidal activities of plant essential oils and some of their isolated constituents against Campylobacter jejuni, Escherichia coli, Listeria monocytogenes, and Salmonella enterica. J. Food Prot. 2002, 65, 1545-1560. [CrossRef] [PubMed]

65. Mathur, S.; Udgire, M.; Khambhapati, A.; Paul, D. Anti-biofilm activity and bioactive component analysis of eucalyptus oil against urinary tract pathogen. Int. J. Curr. Microbiol. Appl. Sci. 2014, 3, 912-918.

66. Karpanen, T.J.; Worthington, T.; Hendry, E.R.; Conway, B.R.; Lambert, P.A. Antimicrobial efficacy of chlorhexidine digluconate alone and in combination with eucalyptus oil, tea tree oil and thymol against planktonic and biofilm cultures of Staphylococcus epidermidis. J. Antimicrob. Chemother. 2008, 62, 1031-1036. [CrossRef] [PubMed]

67. Sharifzadeh, A.; Khosravi, A.R.; Ahmadian, S. Chemical composition and antifungal activity of Satureja hortensis L. essential oil against planktonic and biofilm growth of Candida albicans isolates from buccal lesions of HIV(+) individuals. Microb. Pathog. 2016, 96, 1-9. [CrossRef] [PubMed]

68. Khan, M.S.A.; Ahmad, I.; Cameotra, S.S.; Botha, F. Sub-MICs of Carum copticum and Thymus vulgaris influence virulence factors and biofilm formation in Candida spp. BMC Complement. Altern. Med. 2014, 14, 337. [CrossRef] [PubMed]

69. Agulló, L.; Romero-Silva, M.J.; Domenech, M.; Seeger, M. p-Cymene Promotes Its Catabolism through the $p$-Cymene and the p-Cumate Pathways, Activates a Stress Response and Reduces the Biofilm Formation in Burkholderia xenovorans LB400. PLoS ONE 2017, 12, e0169544. [CrossRef] [PubMed]

70. Bjarnason, I.; Hayllar, J.; MacPherson, A.J.; Russell, A.S. Side effects of nonsteroidal anti-inflammatory drugs on the small and large intestine in humans. Gastroenterology 1993, 104, 1832-1847. [CrossRef]

71. Schacke, H.; Docke, W.D.; Asadullah, K. Mechanisms involved in the side effects of glucocorticoids. Pharmacol. Ther. 2002, 96, 23-43. [CrossRef]

72. Conte, R.; Marturano, V.; Peluso, G.; Calarco, A.; Cerruti, P. Recent Advances in Nanoparticle-Mediated Delivery of Anti-Inflammatory Phytocompounds. Int. J. Mol. Sci. 2017, 18, 709. [CrossRef] [PubMed]

73. Bonifácio, B.V.; Silva, P.B.; Ramos, M.A.; Negri, K.M.; Bauab, T.M.; Chorilli, M. Nanotechnology-based drug delivery systems and herbal medicines: A review. Int. J. Nanomed. 2014, 9, 1-15.

74. Vijayaraghavan, K.; Nalini, S.P.; Prakash, N.U.; Madhankumar, D. One step green synthesis of silver nano/microparticles using extracts of Trachyspermum ammi and Papaver somniferum. Colloids Surf. B Biointerfaces 2012, 94, 114-117. [CrossRef] [PubMed]

75. Keawchaoon, L.; Yoksan, R. Preparation, characterization and in vitro release study of carvacrol-loaded chitosan nanoparticles. Colloids Surf. B Biointerfaces 2011, 84, 163-171. [CrossRef] [PubMed]

76. Bonferoni, M.C.; Sandri, G.; Rossi, S.; Usai, D.; Liakos, I.; Garzoni, A.; Fiamma, M.; Zanetti, S.; Athanassiou, A.; Caramella, C.; et al. A novel ionic amphiphilic chitosan derivative as a stabilizer of nanoemulsions: Improvement of antimicrobial activity of Cymbopogon citratus essential oil. Colloids Surf. B Biointerfaces 2017, 152, 385-392. [CrossRef] [PubMed] 
77. Bio-Synthetic Polymer Conjugates (Advances in Polymer Science), 2013rd ed.; Schlaad, H., Ed.; Springer: Berlin, Germany, 2013.

78. Iannitelli, A.; Grande, R.; Di Stefano, A.; Di Giulio, M.; Sozio, P.; Bessa, L.J.; Laserra, S.; Paolini, C.; Protasi, F.; Cellini, L. Potential antibacterial activity of carvacrol-loaded poly(DL-lactide-co-glycolide) (PLGA) nanoparticles against microbial biofilm. Int. J. Mol. Sci. 2011, 12, 5039-5051. [CrossRef] [PubMed]

79. Souza, M.A.; Oliveira, J.E.; Medeiros, E.S.; Glenn, G.M.; Mattoso, L.H. Controlled Release of Linalool Using Nanofibrous Membranes of Poly(lactic acid) Obtained by Electrospinning and Solution Blow Spinning: A Comparative Study. J. Nanosci. Nanotechnol. 2015, 15, 5628-5636. [CrossRef] [PubMed]

80. Martínez-Sanz, M.; Bilbao-Sainz, C.; Du, W.X.; Chiou, B.S.; Williams, T.G.; Wood, D.F.; Imam, S.H.; Orts, W.J.; Lopez-Rubio, A.; Lagaron, J.M. Antimicrobial Poly(lactic acid)-Based Nanofibres Developed by Solution Blow Spinning. J. Nanosci. Nanotechnol. 2015, 15, 616-627. [CrossRef] [PubMed]

81. Shakeri, F.; Shakeri, S.; Hojjatoleslami, M. Preparation and characterization of carvacrol loaded polyhydroxybutyrate nanoparticles by nanoprecipitation and dialysis methods. J. Food Sci. 2014, 79, N697-N705. [CrossRef] [PubMed]

82. Masood, R.; Hussain, T.; Umar, M.; Azeemullah; Areeb, T.; Riaz, S. In situ development and application of natural coatings on non-absorbable sutures to reduce incision site infections. J. Wound Care 2017, 26, 115-120. [CrossRef] [PubMed]

83. Glinel, K.; Thebault, P.; Humblot, V.; Pradier, C.M.; Jouenne, T. Antibacterial surfaces developed from bio-inspired approaches. Acta Biomater. 2012, 8, 1670-1684. [CrossRef] [PubMed]

84. Ultee, A.; Bennik, M.H.; Moezelaar, R. The phenolic hydroxyl group of carvacrol is essential for action against the food-borne pathogen Bacillus cereus. Appl. Environ. Microbiol. 2002, 68, 1561-1568. [CrossRef] [PubMed]

85. Cristani, M.; D’Arrigo, M.; Mandalari, G.; Castelli, F.; Sarpietro, M.G.; Micieli, D.; Venuti, V.; Bisignano, G.; Saija, A.; Trombetta, D. Interaction of four monoterpenes contained in essential oils with model membranes: Implications for their antibacterial activity. J. Agric. Food Chem. 2007, 55, 6300-6308. [CrossRef] [PubMed]

86. Burt, S.A.; van der Zee, R.; Koets, A.P.; de Graaff, A.M.; van Knapen, F.; Gaastra, W.; Haagsman, H.P.; Veldhuizen, E.J. Carvacrol induces heat shock protein 60 and inhibits synthesis of flagellin in Escherichia coli O157:H7. Appl. Environ. Microbiol. 2007, 73, 4484-4490. [CrossRef] [PubMed]

87. Kisko, G.; Roller, S. Carvacrol and p-cymene inactivate Escherichia coli O157:H7 in apple juice. BMC Microbiol. 2005, 5, 36. [CrossRef] [PubMed]

88. Ultee, A.; Slump, R.A.; Steging, G.; Smid, E.J. Antimicrobial activity of carvacrol toward Bacillus cereus on rice. J. Food Prot. 2000, 63, 620-624. [CrossRef] [PubMed]

89. Cox, S.D.; Mann, C.M.; Markham, J.L. Interaction between components of the essential oil of Malaleuca alternifolia. J. Appl. Microbiol. 2001, 91, 492-497. [CrossRef] [PubMed]

90. Rottanachaikunsopon, P.; Phumkhachorn, P. Synergistic antimicrobial effect of nisin and p-cymene on Salmonella enterica seroval Thyphi in vitro and on ready-to-eat food. Biosci. Biotechnol. Biochem. 2010, 74, 520-524. [CrossRef] [PubMed]

(C) 2017 by the authors. Licensee MDPI, Basel, Switzerland. This article is an open access article distributed under the terms and conditions of the Creative Commons Attribution (CC BY) license (http:/ / creativecommons.org/licenses/by/4.0/). 